\title{
'The Times, They are a Changin': New Editor for CMP in 2019
}

\author{
Atwood D. Gaines ${ }^{1}$
}

Published online: 10 May 2018

(C) Springer Science+Business Media, LLC, part of Springer Nature 2018

This number of CMP concludes my 11th year and begins my 12th as Editor-in-Chief of the Journal. Beginning in January 2019, CMP will have a new Editor-in-Chief. We are pleased to announce that the new Editor-in-Chief is Rebecca Lester, PhD, MSW (LCSW), Associate Professor of Anthropology, of Washington University in St. Louis, Missouri, USA.

Dr. Lester is an academic scholar and a clinician. She is a scholar noted for her work on eating disorders, asceticism and ritual as well as gender and nationalism, community mental health, suicide and her clinical work on eating disorders. The Journal will be in good hands with her. CMP will welcome her aboard in January when her official editorship begins.

Atwood D. Gaines

axg10@case.edu

$1 \quad$ Case Western Reserve University, Cleveland, USA 